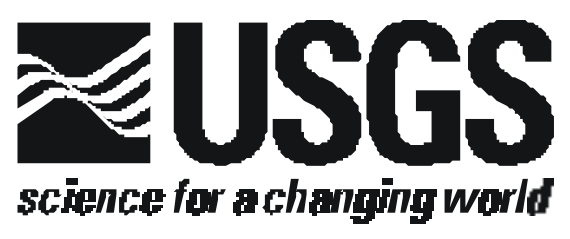

\title{
Geochemical and lead isotopic data from sediment cores, fluvial tailings, iron bogs, and pre-mining terrace deposits, Animas River watershed, Colorado, 1995-1999
}

by

D.L. Fey ${ }^{1}$, S.E. Church ${ }^{1}$, and D.M. Unruh ${ }^{1}$

Open-File Report 00-465

2000

This report is preliminary and has not been reviewed for conformity with U.S. Geological Survey editorial standards and stratigraphic nomenclature. Any use of trade, product, or firm names is for descriptive purposes only and does not imply endorsement by the U.S. Government

\section{U.S. DEPARTMENT OF THE INTERIOR}

U.S. GEOLOGICAL SURVEY

Denver, Colorado 


\section{Table of Contents}

Introduction

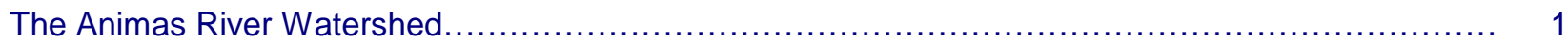

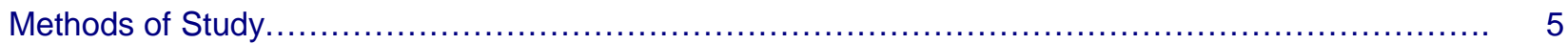

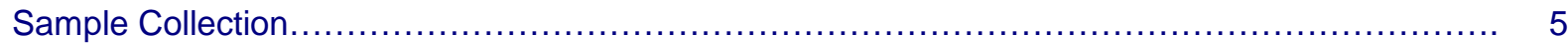

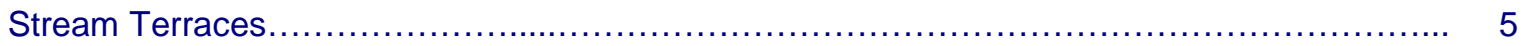

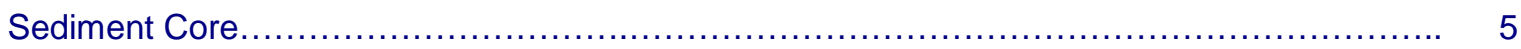

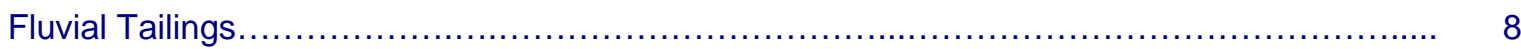

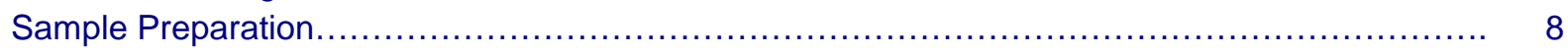

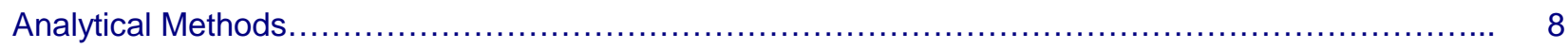

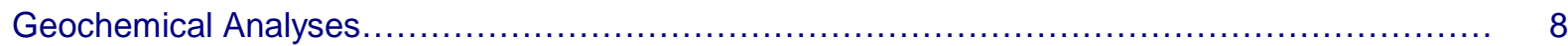

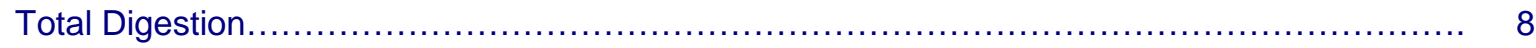

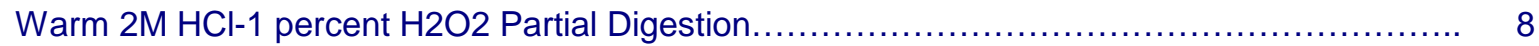

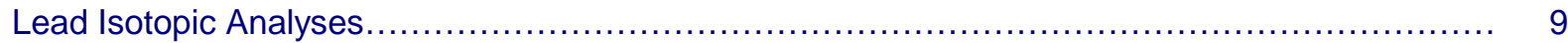

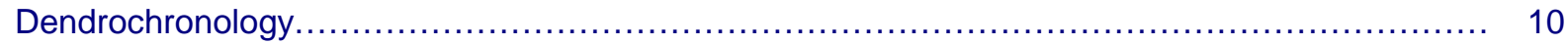

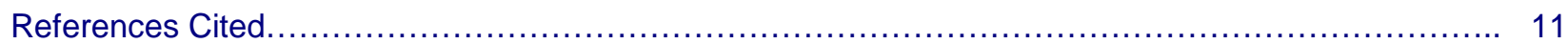

\section{List of Figures}

Figure 1. Elevation and mine site localities, Animas River watershed, Colo........................... 2

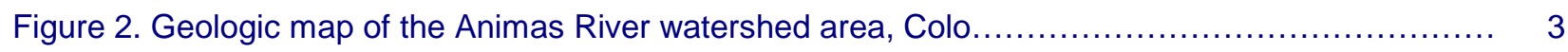

Figure 3. Generalized geologic map of the upper Animas River watershed, Silverton area, Colo......... 4

Figure 4. Sample locality map, upper Animas River watershed, Silverton area, Colo................... 6

Figure 5. Sample locality map, Animas River watershed below Silverton, Colo..................... 7

\section{List of Tables (text in paper)}

Table 10, Elements determined by ICP-AES (inductively coupled plasma-atomic emission

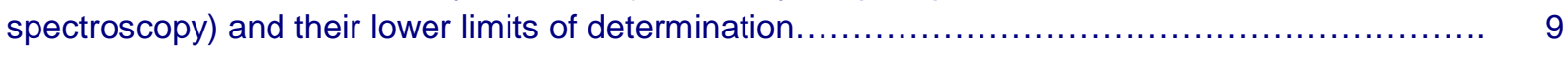

Table 12. Dendrochronology dates from pre-mining background sites, Animas River watershed, Colo... 10 


\section{Table of Contents (continued)}

\section{List of Tables (on website)}

Table 1. Site descriptions, sample types and localities of sediment cores, fluvial tailings, iron bogs, and pre-mining terrace deposits, Animas River watershed, Colo.

Table 2. Sample Descriptions, Mineral Creek basin, Animas River watershed, Colo.

Table 3. Sample Descriptions, Cement Creek basin, Animas River watershed, Colo.

Table 4. Sample Descriptions, upper Animas River basin, Animas River watershed, Colo.

Table 5. Sample Descriptions, Animas River watershed below Silverton, Colo.

Table 6. Major and trace-element data from total digestions of samples, Mineral Creek basin, Animas River watershed, Colo.

Table 7. Major and trace-element data from total digestions of samples, Cement Creek basin, Animas River watershed, Colo.

Table 8. Major and trace-element data from total digestions of samples, upper Animas River basin, Animas River watershed, Colo.

Table 9. Major and trace-element data from total digestions of samples, Animas River watershed below Silverton, Colo.

Table 10. Elements determined by ICP-AES (inductively coupled plasma-atomic emission spectroscopy) and their lower limits of determination.

Table 11. Leachable lead concentration and lead isotopic data from leachates of selected samples, Animas River watershed, Colo.

Table 12. Dendrochronology dates and minimum ages of terraces, Animas River watershed, Colo. 


\section{INTRODUCTION}

The USDA-DOI Abandoned Mine Lands (AML) Initiative (USGS, 1999) is focused on the evaluation of the effect of past mining practices on the water quality and the riparian and aquatic habitats of impacted stream reaches downstream from historical mining districts located primarily on federal lands. This problem is manifest in the eleven western states (i.e., west of $102^{\circ}$ ) where the majority of hardrock mines having past production are located on federal lands (Ferderer, 1996). In areas of temperate climate and moderate to heavy precipitation, the effect of rapid chemical and physical weathering of sulfides exposed on mine waste dumps and the acidic drainage from mines has resulted in elevated metal concentrations in the stream waters and streambed sediment. The result of these processes is an unquantified impact on the quality of the water and the aquatic and riparian habitats, which may limit their recreational resource value. One of the confounding factors in these studies is the determination of the component of metals derived from hydrothermally altered but unmined portions of these drainage basins (Runnells and others, 1992). Several watersheds have been or are being actively studied to evaluate the effects of acid mine drainage (AMD) and acid rock drainage (ARD) on the near-surface environment (USGS, 1997) (http://amli.usgs.gov/amli/5year/). The Animas River watershed in southwestern Colorado contains a large number of past-producing metal mines that have affected the watershed. Beginning in October 1996, the USGS began a collaborative study of these impacts under the USGS-AML Initiative (Buxton and others, 1997).

In this report, we present the geochemical and lead isotopic results of sediment coring work done between 1995 and 1999 in the Animas River watershed. The goals of this overall effort are: 1) to sample pre-mining streambed sediment to define the pre-mining geochemical baseline, 2) to examine existing iron bogs and beaver ponds as possible traps for metals, and 3) to document the geochemical and lead isotopic character of fluvial mill tailings deposits. Many of the samples we collected fall into one of the three categories above, whereas others capture the transition between streambed sedimentary deposits containing fluvial tailings and those unimpacted by historical mining activity. This transition zone usually is not sharp, so making calculations of the mean and median values for pre-mining streambed sediment requires some interpretation of the data (Church and others, 2000a). This work was greatly enhanced by consultations with our colleagues on the project and individual members of the Animas River Stakeholders Group ARSG (1997) .http://www.waterinfo.org/arsg/).

All the data tables in this report are presented as Excel (v. 7) spreadsheet files to facilitate digital transfer and analysis of the data.

\section{THE ANIMAS RIVER WATERSHED}

The Animas River watershed (fig. 1) has its headwaters in the mountainous terrain above Silverton, Colorado and drains south into the San Juan River in northern New Mexico. Elevations range from more than $13,000 \mathrm{ft}$. at the headwaters to less than $6,000 \mathrm{ft}$. at the confluence with the San Juan River near Aztec, New Mexico. The major population center in the basin is the city of Durango, Colo. The geology exposed at the surface and underlying the basin is varied. Precambrian rocks are exposed in the eastern part of the drainage basin south of Silverton (fig. 2), forming the high rugged mountainous area of the Animas Canyon. Paleozoic, Mesozoic, and Cenozoic sedimentary rocks are exposed in the southern part of the drainage basin. The headwaters of the Animas River watershed are underlain by the Tertiary igneous intrusive and volcanic rocks

Figure 1. (page 2) Map of the Animas River watershed (from Church and others, 1997) showing elevation and mine localities from the USGS MRDS, RASS, and PLUTO databases (Ryder, 1994) and the USGS MAS database (Babitzke and others, 1982; McFaul and others, 2000). The digital elevation model data are from USGS (1990), towns, railroads, and roads are from ESRI (1992), and the hydrology data are from USGS (1989).

Figure 2. (page 3) Geologic map (from Church and others, 1997) of the Animas River watershed area (after Tweto, 1979). The digital geology is from Green (1992); hydrology data are from USGS (1989); the towns, railroads, and roads are from ESRI (1992). 


\section{A N IM A S R IV ER W A TER SHED SO U TH WESTERN C OLOR ADO}

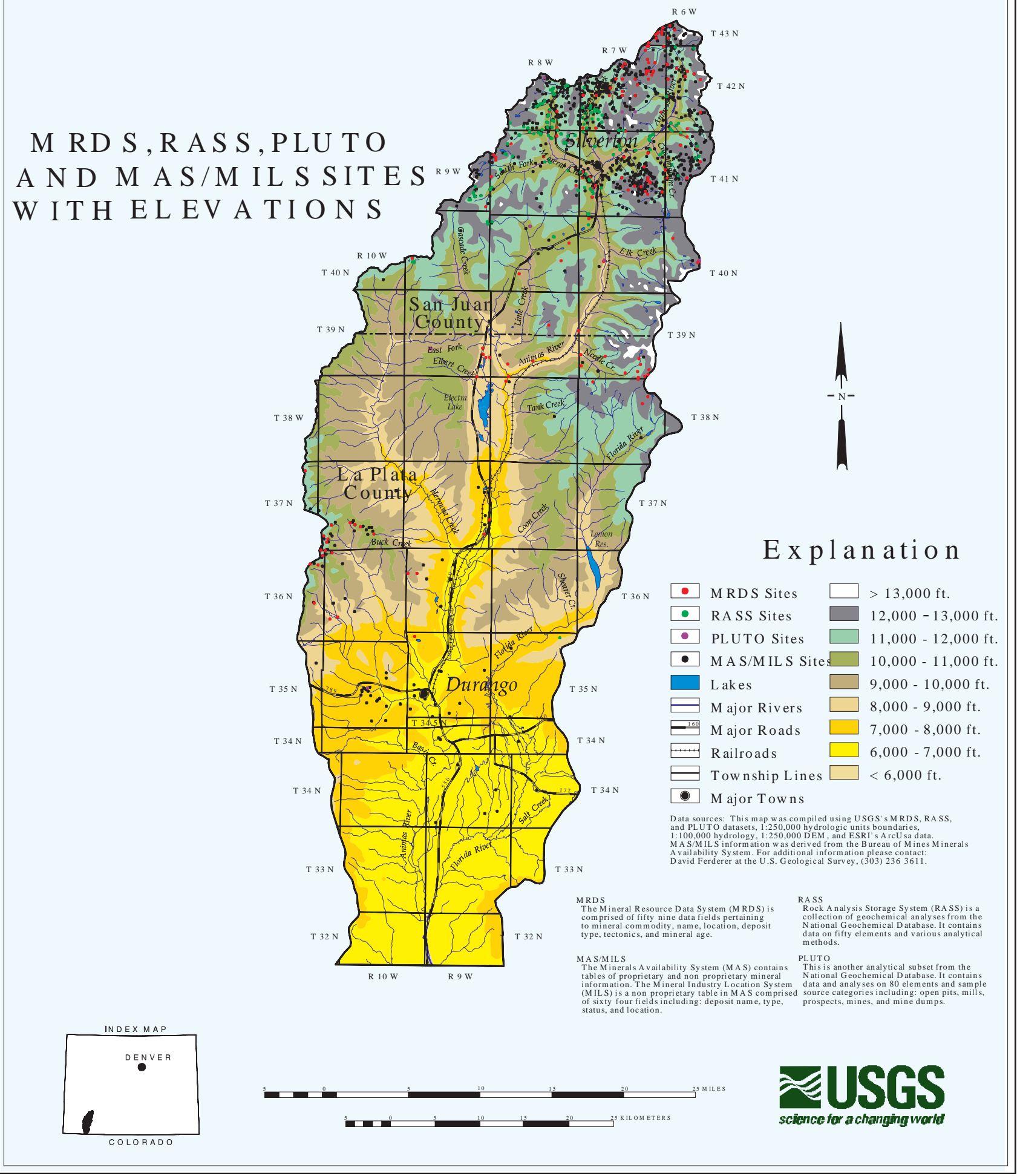




\section{A N IM A S R IVER W A TER SHED SO U T H WESTER N C OLOR ADO}

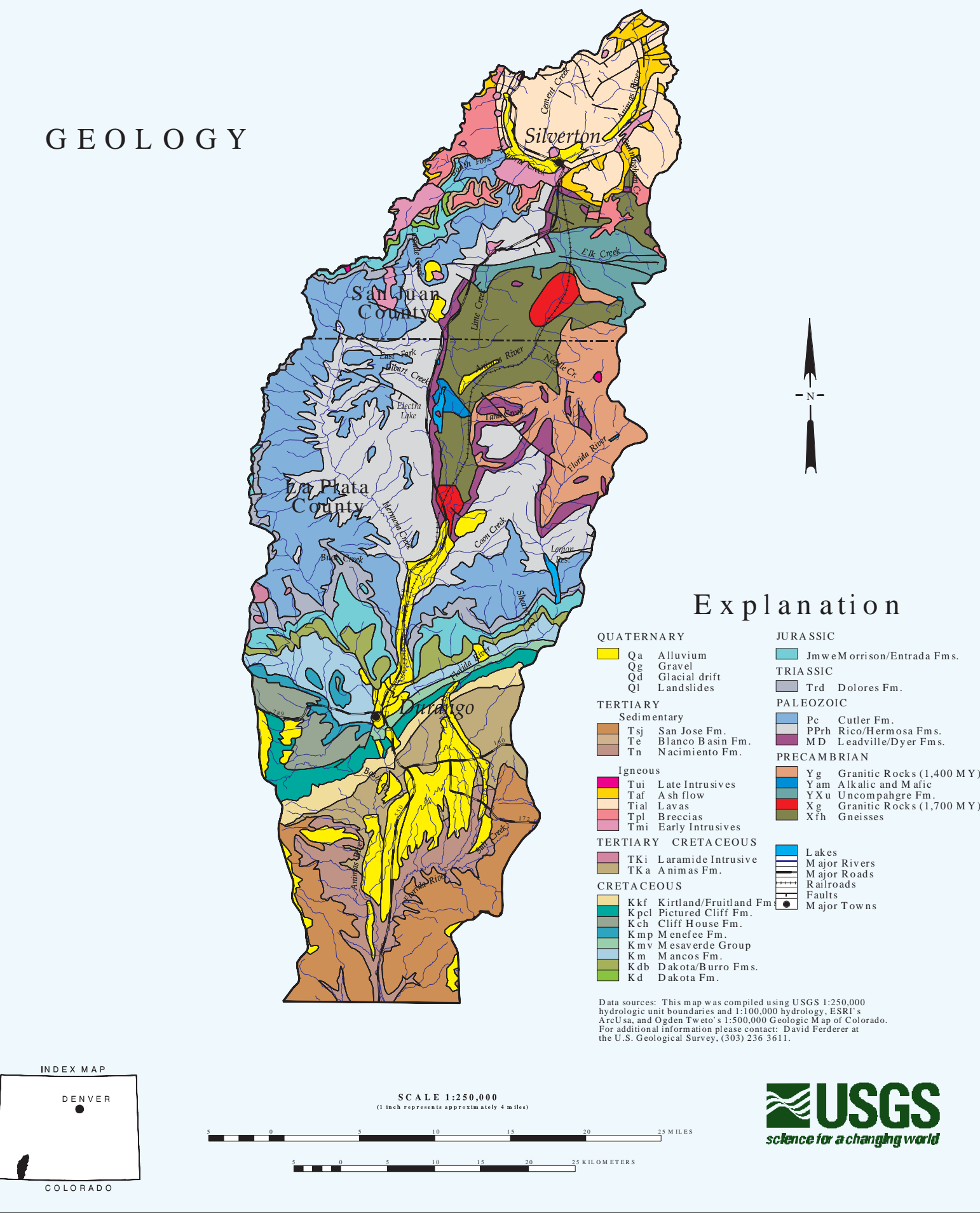


that formed as a result of a late Tertiary age episode of andesitic to dacitic volcanism followed by a later episode of ash-flows, lava flows and intrusions of dacitic to rhyolitic composition (Lipman and others, 1976). During this later episode of volcanism, the Silverton caldera was formed. Pervasive and intense hydrothermal alteration and mineralization events postdate the formation of the Silverton caldera by several million years (Casadevall and Ohmoto, 1977). This area of the Animas River watershed above Silverton has been extensively fractured, hydrothermally altered, and mineralized by Miocene hydrothermal activity.

Gold deposits were discovered in 1871 on Arrastra Creek above Silverton by prospectors who followed the occurrence of placer gold upstream. Following the signing of a treaty with the Ute Indians in 1873, between 1,000 and 1,500 mining claims were staked in the Animas River watershed upstream from Silverton. Mining activity then spread rapidly throughout the area. Chimney deposits (mineralized breccia pipes) in the headwaters of Mineral Creek (fig. 3) were discovered in 1881(see fig 4, Church and others, 1997). A railroad was completed from Durango to Silverton in 1882, providing cheap transportation to the smelters in Durango (Sloan and Skowronski, 1975). Mining continued in the Animas River watershed at various levels of activity until 1991 when the Sunnyside Mine was closed. The extent of mining activity within various portions of the Animas River watershed can be estimated from the distribution of mining claims and from Minerals Availability System (MAS) records (Babitzke and others, 1982; McFaul and others, 2000) within the basin (fig. 1). Mineral deposits in several major mining districts have recorded production. Deposits in the Red Mountain district in the northwestern part of the Silverton caldera, the Eureka district in the Eureka graben within the Silverton caldera, and the South Silverton district along the southern margin of the Silverton caldera east of the town of Silverton (Burbank and Luedke, 1968; Leedy, 1971; Casadevall and Ohmoto, 1977) comprised the majority of the mineral production. There are also several porphyry molybdenum deposits that were discovered by drilling in the Mineral Creek area (oral commun., Tom Casadevall, 1996). Some of the porphyry molybdenum deposits are surrounded by large iron bogs at the surface. Iron bogs are found elsewhere within the basin, associated with springs flowing from mineralized and altered areas within the basin (Mast and others, 2000).

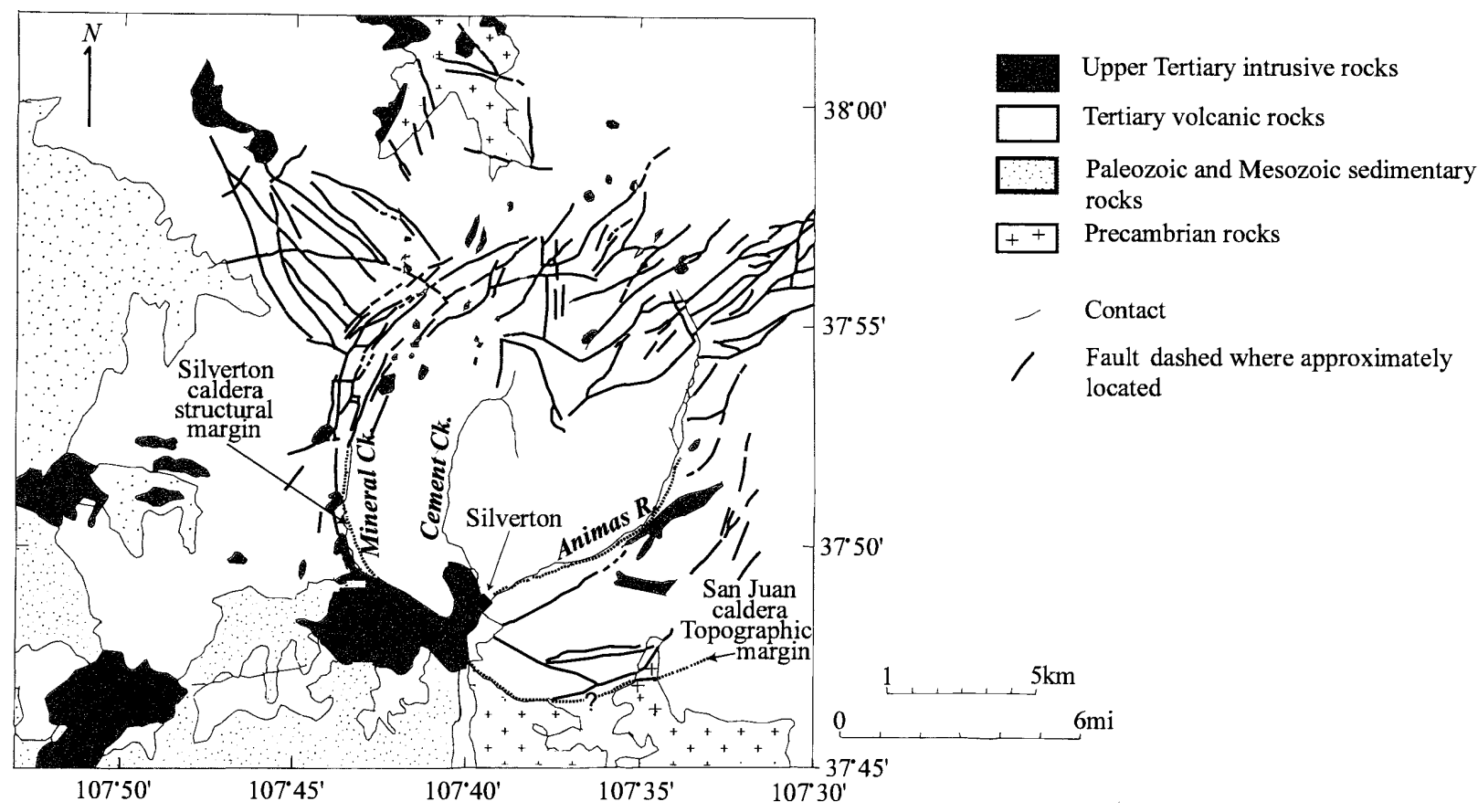

Figure 3. Generalized geologic map of the upper Animas River watershed. The Animas River and Mineral Creek follow the structural margin of the Silverton caldera. In addition to the ring-fractures that were created when the Silverton and the earlier San Juan calderas formed, radial and graben faults, which host much of the subsequent vein mineralization, are shown schematically (modified from Casadevall and Ohmoto, 1977). 


\section{METHODS OF STUDY}

\section{Sample Collection}

Numerous samples were collected to address the three goals outlined above. The sample sites are indicated in figures 4 and 5 , and individual sample localities and sample types are listed in table 1 . Whereas we have referred to the above samples as cores, some are actually samples of streambed gravels that were dry-sieved to minus- $2 \mathrm{~mm}$ in the field, and the fine-grained fraction retained, providing a sample directly analogous to the streambed-sediment samples in Church and others (2000b). Dendrochronology (tree ring) samples were taken at several sites to provide minimum ages of the terraces from which pre-mining streambed samples were obtained. Sample descriptions are in tables 2-5. Table 2 contains descriptions for samples from the Mineral Creek drainage, table 3 contains descriptions for samples from Cement Creek, table 4 contains descriptions for samples taken from the Animas River above Silverton, and table 5 contains descriptions for samples taken from the Animas River below Silverton. The geochemical data for the samples are in tables 6-9, in an analogous sequence. Note that the description tables (2-5) contain more subsamples than the analytical data tables (6-9). This is because we provide the descriptions and depths for all subsamples from all core (or lift) samples, while only a percentage of subsamples was actually analyzed and reported.

\section{Stream Terraces}

Samples of stream terraces were collected and given letter designations, with "a" being the highest sample stratigraphically (tables 2-9). In general, stratigraphy could not be discerned in these gravel deposits, so each sample is really a vertical subsample of the gravel deposit. Each subsample was dry-sieved through a 2-mm (10 mesh) stainless-steel screen in the field. The minus-2-mm fraction for each subsample was retained separately; the larger size fractions were discarded. Samples collected by this method are designated as "lifts" in the data tables. Each subsample was processed separately and the resulting geochemical data evaluated for homogeneous distributions (with depth) of ore-related trace elements ( $\mathrm{As}, \mathrm{Ag}, \mathrm{Cd}, \mathrm{Cu}, \mathrm{Pb}, \mathrm{Zn}$ ) throughout the terrace gravel deposit. Samples from terrace sediment intervals having a uniform trace elemental distribution were used to calculate the pre-mining geochemical baseline concentrations reported in Church and others (2000a). Selected samples were also used to determine the lead isotopic composition of the pre-mining bed sediments.

\section{Sediment Cores}

Sediment cores were collected by driving and subsequently extracting acid-cleaned sections of 2-inch (5$\mathrm{cm})$ or 4-inch $(10-\mathrm{cm})$ diameter PVC pipe into suitable terrace sites. These cores' material was then divided into subsamples based on stratigraphic (where applicable), color, or grain size differences; the subsamples were analyzed for metal content and lead isotopic signatures. All of the cores through iron bogs and modern beaver ponds were 2-inch cores. Some of the cores through fluvial tailings deposits in the upper Animas River basin below the townsite of Eureka were 4-inch diameter cores (sites B-18, B-19 and B-23). Most of the cores through pre-mining sediment terraces were 2-inch cores, with core 98ABB235 at site B-15 on Cement Creek being the exception.

Recognizing pre-mining streambed sediment in the field based on physical characteristics was not easy; determination of pre-mining sediment was based largely on the geomorphological position of terrace deposits (Church and others, 2000a; K. Vincent, unpublished data, 2000) and then confirmed by subsequent geochemical analysis (based on low, consistent values of ore-related elements). Elevated and variable concentrations of zinc in the core sequence at a particular site in the absence of variation in the concentrations of the other ore-related trace elements listed above were interpreted to be possible groundwater contamination, particularly if associated with elevated manganese. The objective of our sampling strategy was to sample sediments deposited throughout the time period that includes the onset of historical mining activity. Thus, concentrations of ore-related trace elements in the cores or lift samples should decrease with depth or reach a consistent concentration, providing a clear indication of the pre-mining geochemical baseline in the streambed sediment. 

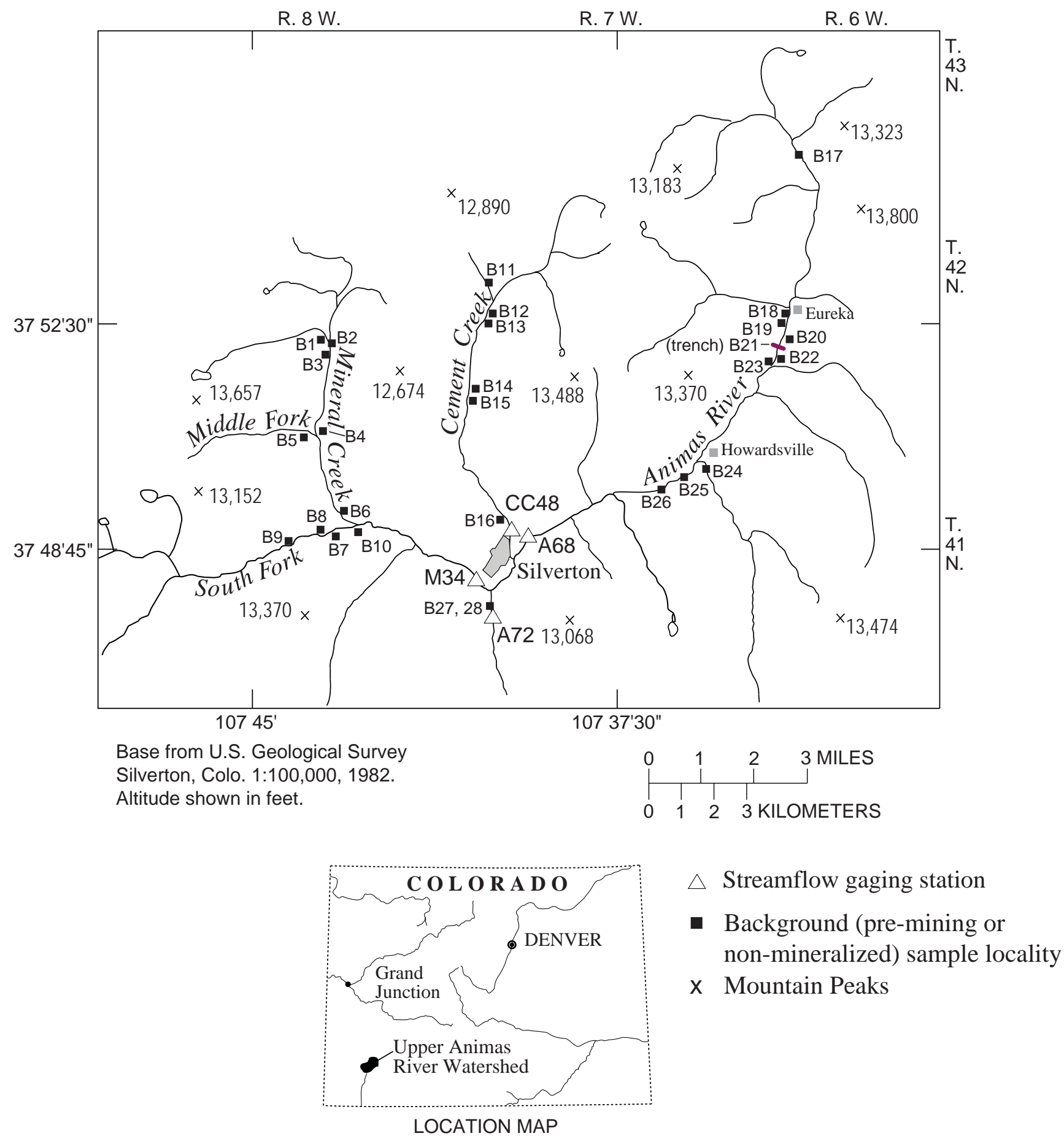

Figure 4. Sample locality map for sediment cores (or lifts) collected in the Mineral Creek, Cement Creek, and upper Animas River basins. 


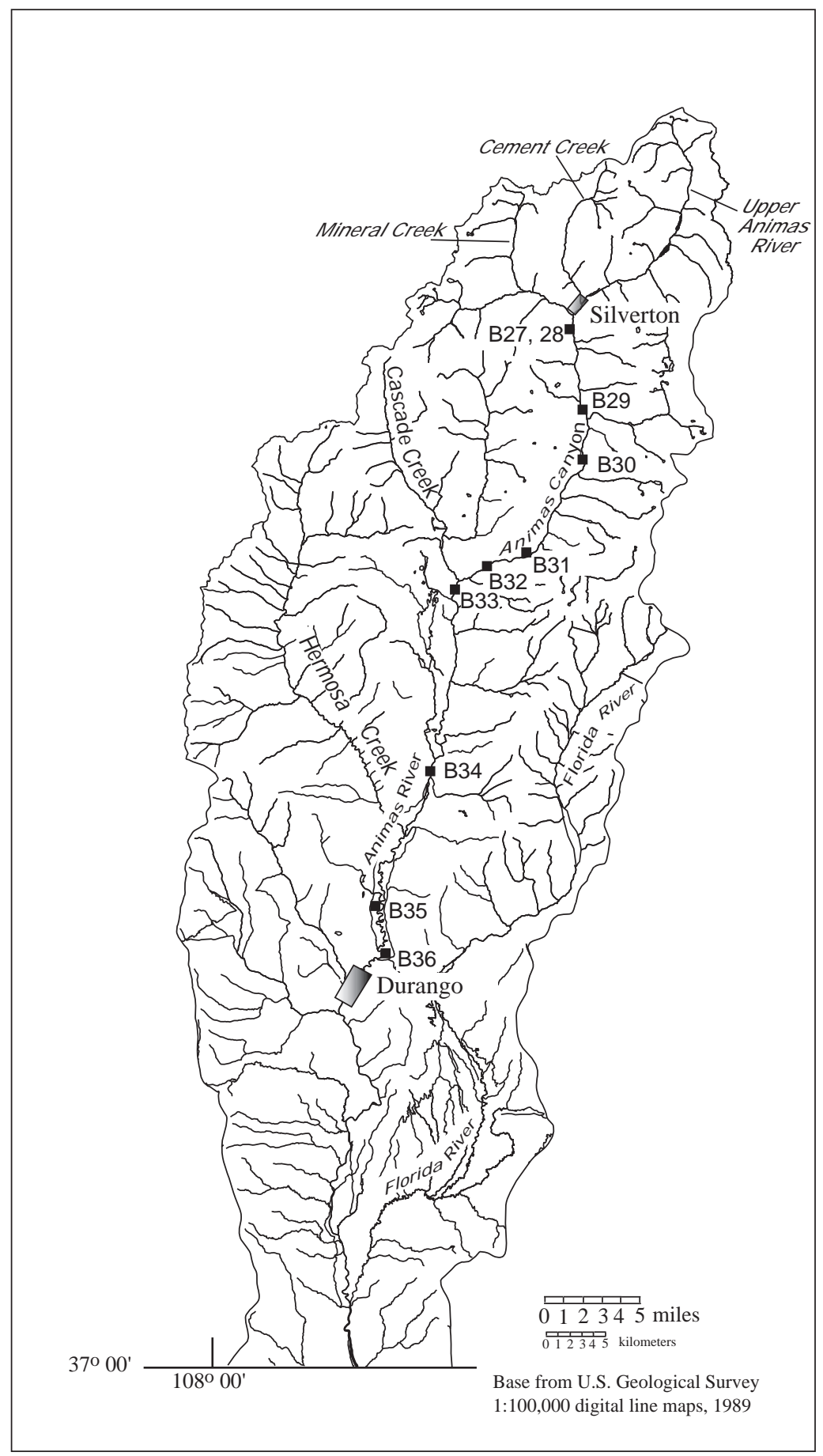

Figure 5. Sample locality map for sediment cores (and lifts) collected in the Animas River watershed below Silverton, Colo. (see fig. 4 for sample localities from the Mineral Creek, Cement Creek and upper Animas River basins). 


\section{Fluvial Mill-Tailings Deposits}

Mill tailings deposits were sampled along the upper Animas River reach below Eureka. Deposits resulting from jig tailings (prior to 1915) and from flotation tailings (after 1915) occur downstream from the Eureka mill site. Tailings were also deposited on an island downstream from the Mayflower mill at site B-26 during the Gladstone flood of 1911 (Pruess, 1996). Tailings deposits also occur in fluvial deposits downstream from Silverton at site B29 (Elk Park) and at site B36 in an oxbow lake that was an active meander as shown on the 1898 topographic map of the Durango quadrangle (USGS, 1898).

\section{Sample Preparation}

Streambed-terrace gravel samples were dried at ambient room temperature $\left(25^{\circ} \mathrm{C}\right)$ and sieved to minus100 -mesh $(<0.18 \mathrm{~mm})$ prior to laboratory analyses.

Core samples were subdivided in the laboratory on the basis of mineralogy, organic content, and apparent oxidation zones. The depth assigned to each subsample is defined as the mid point for that subsample after taking core compaction into account (tables 2-5). Core compaction was determined by measuring in the field the depth of penetration of the core casing, and then measuring the length of the core itself. Individual cores were generally divided into two to ten subsamples, air dried, sieved if the grain size exceeded that of fine sand $(0.125-0.25 \mathrm{~mm})$ and the fines retained, and then ground in random order to minus 100 mesh in a vertical pulverizer.

\section{ANALYTICAL METHODS AND RESULTS}

\section{Geochemical Analyses}

\section{Total Digestion}

The samples were digested with a mixed-acid procedure consisting of hydrochloric, nitric, perchloric, and hydrofluoric acids $\left(\mathrm{HCl}, \mathrm{HNO}_{3}, \mathrm{HClO}_{4}\right.$, and $\left.\mathrm{HF}\right)$ (Crock and others, 1983; Briggs, 1996). This procedure is effective in dissolving most minerals, including silicates, oxides and sulfides; resistant or refractory minerals such as zircon, chromite, and some tin oxides are only partially dissolved. Previous investigations using a variety of materials support the completeness of the digestion (Church, 1981, Church and others, 1987; Wilson and others, 1994).

Results are reported for 34 elements determined by ICP-AES (inductively coupled plasma-atomic emission spectroscopy; (Briggs, 1996) in tables 6-9. The percent ash contents of samples containing organic matter are also provided for samples that were ashed prior to analysis. For those samples, the reported elemental values have been recalculated to the original sample weight. Limits of determination for the ICP-AES total digestion method as well as a statistical summary of mean values, standard deviations, and median values for four National Institute of Standards and Technology (NIST) standard reference materials (SRM-2704, SRM-2709, SRM-2710, and SRM-2711) are given by Fey and others (1999). Limits of determination for the ICP-AES determination are also given below in table 10. Comparisons with certified values for these standards (NIST, 1993a; 1993b; 1993c; and 1993d) are also given by Fey and others (1999). Both analytical precision and accuracy are well within acceptable ranges. Analytical results for the samples reported here are directly comparable with results from the modern streambed-sediment samples reported in Church and others (2000b).

\section{Warm 2M HCl-1 Percent $\mathrm{H}_{2} \mathrm{O}_{2}$ Partial Digestion}

The use of a partial-digestion extraction enables one to determine concentrations of trace elements bound within different mineral phases, whereas a total digestion releases all trace elements in a sample (Chao, 1984). The leaching solution used in this study, a daily-prepared mixture of $2 \mathrm{M} \mathrm{HCL}$ and 1 percent hydrogen peroxide $\left(\mathrm{H}_{2} \mathrm{O}_{2}\right)$, dissolves known elemental sinks such as hydrous amorphous iron-, manganese-, and aluminum oxide minerals, as well as some crystalline iron- and manganese-oxides. (Church and others, 1993). This leach also dissolves water-soluble, ion-exchangeable, and carbonate species. We used a 2.0-g sample in $15 \mathrm{~mL}$ of reagent on selected samples to provide solutions for the lead isotopic determinations. 
Table 10. Elements determined by ICP-AES (inductively coupled plasma-atomic emission spectroscopy) and their lower limits of determination. These limits apply to a standard sample weight of $0.2 \mathrm{~g}$; when smaller weights are used, the determination limits are correspondingly higher. Analyses performed at the USGS laboratories in Denver, Colo.

\begin{tabular}{|c|c|c|c|c|c|}
\hline Element & Symbol & $\begin{array}{l}\text { Lower limit } \\
\text { of determination }\end{array}$ & Element & Symbol & $\begin{array}{c}\text { Lower limit } \\
\text { of determination }\end{array}$ \\
\hline Aluminum & $\overline{\mathrm{Al}}$ & $0.01 \%$ & Chromium & $\overline{\mathrm{Cr}}$ & "1 ppm \\
\hline Calcium & $\mathrm{Ca}$ & $0.01 \%$ & Copper & $\mathrm{Cu}$ & $1 \mathrm{ppm}$ \\
\hline Iron & $\mathrm{Fe}$ & $0.01 \%$ & Gallium & $\mathrm{Ga}$ & 4 ppm \\
\hline Potassium & $\mathrm{K}$ & $0.01 \%$ & Lanthanum & La & 2 ppm \\
\hline Magnesium & $\mathrm{Mg}$ & $0.01 \%$ & Lithium & $\mathrm{Li}$ & 2 ppm \\
\hline Sodium & $\mathrm{Na}$ & $0.01 \%$ & Molybdenum & Mo & 2 ppm \\
\hline Phosphorous & $P$ & $0.01 \%$ & Niobium & $\mathrm{Nb}$ & 4 ppm \\
\hline Titanium & $\mathrm{Ti}$ & $0.01 \%$ & Neodymium & $\mathrm{Nd}$ & 4 ppm \\
\hline Manganese & $\mathrm{Mn}$ & 4 ppm & Nickel & $\mathrm{Ni}$ & 2 ppm \\
\hline Silver & $\mathrm{Ag}$ & 2 ppm & Lead & $\mathrm{Pb}$ & 4 ppm \\
\hline Arsenic & As & 10 ppm & Scandium & Sc & 2 ppm \\
\hline Barium & $\mathrm{Ba}$ & $1 \mathrm{ppm}$ & Strontium & $\mathrm{Sr}$ & 2 ppm \\
\hline Beryllium & $\mathrm{Be}$ & 1 ppm & Thorium & Th & 4 ppm \\
\hline Bismuth & $\mathrm{Bi}$ & 10 ppm & Vanadium & V & 2 ppm \\
\hline Cadmium & $\mathrm{Cd}$ & 2 ppm & Yttrium & $Y$ & 2 ppm \\
\hline Cerium & $\mathrm{Ce}$ & 4 ppm & Ytterbium & $\mathrm{Yb}$ & 1 ppm \\
\hline Cobalt & Co & 1 ppm & Zinc & $\mathrm{Zn}$ & 2 ppm \\
\hline
\end{tabular}

The samples were placed in $90 \mathrm{~mL}$ Teflon FEP jars, sealed, and placed in an agitating waterbath at $50^{\circ} \mathrm{C}$ for three hours to ensure complete removal of the iron- and manganese-oxide coatings from the sediment grains. The leachates were subsequently analyzed by ICP-AES (Appendix III in Church and others, 1993). This partial extraction releases trace elements associated with hydrous amorphous iron- and manganese-oxide mineral coatings and colloidal particles. Mineral coatings such as those observed in the study area contain a significant percentage of the trace elements in a sample (Church and others, 1993, 1997). The lead concentration and isotopic data are reported in table 11.

\section{Lead Isotopic Analyses}

The vast majority of the contaminant lead exists within the amorphous iron- and manganese-oxide mineral coatings and colloidal particles (Church and others, 1993, 1994, 1995, 1997); only the leachates from selected samples of the pre-mining streambed sediment were analyzed for lead isotopic compositions. These data are comparable to the lead isotopic data in tables 7 and 8 in Church and others (2000b), and provide a measure of the effect of exposed and near-surface mineralization on the pre-mining streambed sediment geochemical baseline within the Animas River watershed. Lead-isotopic analysis of the leachate solutions greatly reduces dilution effects from lead bound within major mineral phases such as potassium-feldspar and volcanic glassy rock matrix that would be encountered if we had used the total digestion solution from the samples.

The lead-isotopic work was carried out using a VG Sector-54 multi-collector mass spectrometer. Lead was separated using the procedure described below with minor variations (see appendix IV of Church and others, 1993; Tatsumoto and Unruh, 1976; and Unruh and others, 1979). The ICP-AES concentration value for lead (table 11) was used to calculate the volume of leachate needed to contain approximately $0.5 \mu \mathrm{g}$ of lead; this aliquot was then evaporated to dryness in a teflon beaker. Then 0.5 to $1.0 \mathrm{~mL}$ of $1.0 \mathrm{~N}$ hydrobromic acid $(\mathrm{HBr}$ ) was added to the sample and warmed gently for 5 to 10 minutes. The sample was allowed to cool, was centrifuged, and the supernatant loaded onto an anion-exchange column (0.8-1.0 mL resin volume) using Dowex AG1-x8 anion-exchange resin. The column was washed with $1.2 \mathrm{~N} \mathrm{HBr}$ and water, and then the lead 
was eluted with either $8 \mathrm{~N} \mathrm{HCl}$ or $0.5-1.0 \mathrm{~N} \mathrm{HNO}_{3}$. The eluted lead sample was again evaporated to dryness and then loaded onto a second anion-exchange column with a resin volume of 0.1-0.2 mL. The column was washed with $1.2 \mathrm{~N} \mathrm{HBr}$ and water, and the lead was eluted with $0.5 \mathrm{~N} \mathrm{HNO}_{3}$. Two or three drops of dilute (0.25-0.5 percent) phosphoric acid $\left(\mathrm{H}_{3} \mathrm{PO}_{4}\right)$ were added to the eluted lead sample, and then it was evaporated again to dryness.

Approximately one-half of the sample was taken up in approximately $10 \mu \mathrm{L}$ of dilute colloidal silica gel, loaded onto a rhenium-ribbon filament, and evaporated to dryness. The filament was then loaded into a solidsource, thermal-ionization mass spectrometer and heated to $1150-1350^{\circ} \mathrm{C}$ for data acquisition. Most analyses were made using a VG Sector 54, 7-collector mass spectrometer run in "static" mode. A few samples were run on a VG Isomass 54R, single-collector mass spectrometer. No systematic biases have been observed between the two mass spectrometers (Taylor and others, 1999). Analyses of NIST SRM-981 were used to monitor mass fractionation during mass spectrometry (Cantanzaro and others, 1968; Todt and others, 1993). Methods of calculation of the analytical uncertainty and replicate analyses of the SRM-981 lead isotopic standard are presented in Unruh and others (2000). Analytical results are in Table 11.

As demonstrated by Fey and others (1999), data from analyses of the leachates are inherently less reproducible than those from total digestion analyses. As a test of the leaching procedure for lead isotopic analyses, leachates of four NIST standards SRM-2704, SRM-2709, SRM-2710, and SRM-2711 were analyzed for lead isotopic ratios. The lead isotopic analyses of replicate solutions of the four NIST standards are in good agreement with previous work (Church and others, 1993).

\section{Dendrochronology}

Cores of live trees were sampled using a standard tree corer. The core was extracted and placed in a plastic sleeve, and sent to the Laboratory for Tree Ring Research at the University of Arizona for dendrochronological analysis. Slabs of dead trees were also sent for analysis in hopes that the year of death could be determined to date the tree stump. The age of the trees provides an estimate of the minimum age of the stream terrace (table 12). Cores or slabs from sample sites B-4, B-6, B-15, B-17, and B-24 were from Engelmann spruce; the slab from site B-30 was from a Mountain cottonwood.

Table 12. Dendrochronology dates from pre-mining background sites, Animas River watershed, Colo. [Dendrochronology done at the Laboratory for Tree Ring Research, University of Arizona, Tucson, Ariz.]

\begin{tabular}{|l|l|c|}
\hline Site & Sample & $\begin{array}{c}\text { Year (minimum age } \\
\text { of terrace) }\end{array}$ \\
\hline B-4 & Live tree & 1915 (85 years) \\
\hline B-6 & Dead tree stump; tree rings complacent, no chronological data available. & 1876 (124 years) \\
\hline B-15 & Live tree. & 1858 (142 years) \\
\hline B-17 & Dead tree stump; tree rings complacent, no chronological data available. & 1922 (78 years) \\
\hline B-24 & Live tree. & 1936 (64 years) \\
\hline B-30 & Dead tree stump; tree rings complacent, no chronological data available. & 1957 )43 years) \\
\hline
\end{tabular}




\section{REFERENCES CITED}

ARSG, 1997, Web page for Animas River Stakeholders Group. Accessed November 7, 2000 at http://www.waterinfo.org/arsg/).

Babitzke, H.R., Barsotti, A.F., Coffman, J.S., Thompson, J.G., and Bennett, H.J., 1982, The Bureau of Mines Minerals Availability System: An update of the Information Circular 8654: U.S. Bureau of Mines Circular $8815,24 \mathrm{p}$.

Briggs, P.H., 1996, Forty elements by inductively coupled-plasma atomic emission spectrometry, in Arbogast, B.F., ed., Analytical methods manual for the Mineral Resources Program, U.S. Geological Survey: U.S. Geological Survey Open-File Report 96-525, p. 77-94.

Buxton, H.T., Nimick, D.A., von Guerard, Paul, Church, S.E., Frazier, Ann, Gray, J.R., Lipin, B.R., Marsh, S.P., Woodward, Daniel, Kimball, Briant, Finger, Susan, Ischinger, Lee, Fordham, J.C., Power, M.S., Bunck, Christine, and Jones, J.W., 1997, A science-based, watershed strategy to support effective remediation of abandoned mine lands: in Fourth Annual International Conference on Acid Rock Drainage Proceedings, v. IV, Vancouver, B.C. Canada, May 31-June 5, 1997, p. 1869-1880.

Burbank, W.S., and Luedke, R.G., 1968, Geology and ore deposits of the San Juan Mountains, Colorado, in Ridge, J.D., ed., Ore deposits of the United States, 1933-1967: New York, American Institute of Mining, Metallurgical, and Petroleum Engineers, p. 714-733.

Casadevall, T., and Ohmoto, H., 1977, Sunnyside mine, Eureka mining district, San Juan County, Colorado: Geochemistry of gold and base metal ore deposition in a volcanic environment: Economic Geology, v. 92, p. 1285-1320.

Cantanzaro, E.J., Murphy, T.J., Shields, W.R., and Garner, E.L., 1968, Absolute isotopic abundance ratios of common, equal atom, and radiogenic lead isotopic standards: Journal of Research of the National Bureau of Standards, v. 72A, p. 261-267.

Chao, T.T., 1984, Use of partial dissolution techniques in geochemical exploration: Journal of Geochemical Exploration, v. 20, p. 101-135.

Church, S.E., 1981, Multielement analysis of fifty-four geochemical reference samples using inductively coupled plasma-atomic emission spectrometry: Geostandards Newsletter, v. 5, p. 133-160.

Church, S.E., Mosier, E.L., and Motooka, J.M., 1987, Mineralogical basis for the interpretation of multielement (ICP-AES), oxalic acid, and aqua-regia partial digestions of stream sediments for reconnaissance exploration geochemistry: Journal of Geochemical Exploration, v. 29, p. 207-233.

Church, S.E., Holmes, C.E., Briggs, P.H., Vaughn, R.B., Cathcart, James, and Marot, Margaret, 1993, Geochemical and lead-isotope data from stream and lake sediments, and cores from the upper Arkansas River drainage: Effects of mining at Leadville Colorado on heavy-metal concentrations in the Arkansas River: U.S. Geological Survey Open-File Report 93-534, 61 p.

Church, S.E., Wilson, S.A., Vaughn, R.B., and Fey, D.L., 1994, Geochemical and lead-isotopic studies of river and lake sediments, upper Arkansas River basin, Twin Lakes to Pueblo, Colorado: U.S. Geological Survey Open-File Report 94-412, $44 \mathrm{p}$.

Church, S.E., Wilson, S.A., and Briggs, P.H., 1995, Geochemical and lead-isotopic studies of stream and river sediments, Alamosa River basin, Colorado: U.S. Geological Survey Open-File Report 95-250, 71 p.

Church, S.E. Kimball, B.A., Fey, D.L., Ferder, D.A. Yager, T.J., and Vaughn, R.B., 1997, Source, transport, and partitioning of metals between water, colloids, and bed sediments of the Animas River, Colorado: U.S. Geological Survey Open-File Report 97-151, 136 p.

Church, S.E., Fey, D.L., and Blair, Robert, 2000a, Pre-mining bed sediment geochemical baseline in the Animas River watershed, southwestern Colorado, in ICARD 2000 Proceedings from the Fifth International Conference on Acid Rock Drainage, SME, Littleton, Colo., V. 1, p. 499-512.

Church, S.E., Fey, D.L., Unruh, D.M., Vaughn, R.B., and Taggart, J.E., Jr., 2000b, Geochemical and isotopic data from streambed sediment, Animas River watershed, Colorado, 1995-1999: U.S. Geological Survey Open-File Report 00-244, (available at: http://greenwood.cr.usgs.gov/pub/open-file-reports/ofr-00-0244/).

Crock, J.G., Lichte, F.E., and Briggs, 1983, Determination of elements in National Bureau of Standards geologic reference materials SRM 278 obsidian and SRM 688 basalt by inductively coupled plasmaatomic emission spectroscopy: Geostandards Newsletter, v. 7, p. 335-340.

Environmental Systems Research Institute (ESRI), 1992, ARCUSA 1:2,000,000 CDROM - Digital Atlas of the United States and the Caribbean Outlying Areas, Redlands, Calif. 
Ferderer, D.A., 1996, National overview of abandoned mine land sites utilizing the minerals availability system (MAS) and geographic information systems (GIS) technology: U.S. Geological Survey Open-File Report 96-549, $42 \mathrm{p}$.

Fey, D.L., Unruh, D.M., and Church, S.E., 1999, Chemical data and lead isotopic composition in streamsediment samples from the Boulder River watershed, Jefferson County, Montana: U.S. Geological Survey Open-File Report 99-575, 147 p.

Lipman, P.W., Fisher, F.S., Mehnert, H.H., Naeser, C.W., Luedke, R.G., and Steven, T.A., 1976, Multiple ages of mid-Tertiary mineralization and alteration in the western San Juan Mountains, Colorado: Economic Geology, v. 71, p. 571-588.

Leedy, W.P., 1971, Hydrothermal alteration of volcanic rocks in the Red Mountain district of the San Juan Mountains, Colorado: Ph. D. dissertation, State University of New York, Buffalo, 165 p.

Mast, M.A., Verplank, P.L., Yager, D.B., Wright, W.G., and Bove, D.J., 2000, Natural sources of metals to surface waters in the upper Animas River watershed, Colorado, in Proceedings of the Fifth International Conference on Acid Rock Drainage, May 20-23, 2000, Denver, Colorado, Society of Mining Engineering, Lakewood, Colo., $10 \mathrm{p}$, (in press).

McFaul, E.J., Mason, G.T., Jr., Ferguson, W.B., and Lipin, B.R., 2000, U.S. Geological Survey Mineral databases-MRDS and MAS/MILS: U.S. Geological Survey Digital Data Series DDS-52, two CDROM discs.

National Institute of Standards and Technology (NIST), 1993a, Certificate of Analysis Standard Reference material 2704, Buffalo River Sediment. , 1993b, Certificate of Analysis Standard Reference material 2709, San Joaquin Soil. 1993c, Certificate of Analysis Standard Reference material 2710, Contaminated Montana Soil. ,1993d, Certificate of Analysis Standard Reference material 2711, Montana Soil.

Pruess, Jonathan, 1996, Paleoflood reconstructions within the Animas River Basin upstream from Durango, Colorado, M.S. Thesis: Colorado State University, Fort Collins.

Runnells D.D., Shephard, T.A., and Angino, E.E., 1992, Metals in water-Determining natural background concentrations of dissolved components in water at mining, milling, and smelting sites: Mining Engineering, v. 50, p. 65-71.

Ryder, J.L., 1994, Active- and inactive-, and abandoned-mine information and selected geochemical data for the state of Colorado: U.S. Geological Survey Open-File Report 94-579, diskette version, $6 \mathrm{p}$.

Sloan, R.E., and Skowronski, C.A., 1975, The Rainbow Route, an Illustrated History of the Silverton Railroad, the Northern Silverton Railroad, and the Silverton, Gladstone, \& Northerly Railroad, Denver, Colo.: Sundance Publications Limited, $416 \mathrm{p}$.

Tatsumoto, M., and Unruh, D.M., 1976, KREEP basalt age: Grain by grain U-Th-Pb systematics study of the quartz monzodiorite clast 15405,88: Proceedings of the $7^{\text {th }}$ Lunar Science Conference, p. 2107-2129.

Taylor, H.E., Antweiler, R.C., Alpers, C.N., Roth, D.A., Brinton, T.I., Cain, D.J., Ball, J.W., Unruh, D.M., and Dileanis, P.D., 1999, Quality assurance and control, in Alpers, C.N., Taylor, H.E., and Domagalski, J.L., eds., Metals transport in the Sacramento River, California, 1996-1997, Volume 1: Methods and data: Water Resources Investigations Report 99-4286, p. 38-59.

Todt, W., Cliff, R.A., Hanser, A., and Hofmann, A.W., 1993, Re-calibration of NBS lead standards using a ${ }^{202} \mathrm{~Pb}-{ }^{205} \mathrm{~Pb}$ double spike: Abstracts presented to the $7^{\text {th }}$ meeting of the European Union of Geosciences, p. 396.

Tweto, Ogden, 1979, Geologic map of Colorado: U.S. Geological Survey, scale, 1:500,000.

Unruh, D.M., Hutchison, R., and Tatsumoto, M., 1979, U-Th-Pb age of the Barwell chondrite: Anatomy of a discordant meteorite: Proceedings of the $10^{\text {th }}$ Lunar and Planetary Science Conference, p. 1011-1030.

Unruh, D.M., Fey, D.L., and Church, S.E., 2000, Chemical data and lead isotopic compositions of geochemical baseline samples from streambed sediments and smelter slag, lead isotopic compositions of fluvial tailings, and dendrochronology results from the Boulder River watershed, Jefferson County, Montana: U.S. Geological Survey Open-File Report 00-038, 75 p.

U.S. Geological Survey (USGS), 1898, Topographic map of the Durango quadrangle, Colo.

U.S. Geological Survey (USGS), 1989, Digital Line Graphs from 1:100,000-scale maps: U.S. Geological Survey Data Users Guide 2, 88 p. 
, 1990, Digital Elevation Models: U.S. Geological Survey Data Users Guide 5, $51 \mathrm{p.}$

1997, Abandoned Mine Lands Project Plan web page. Accessed November 8, 2000 at URL http://amli.usgs.gov/amli/5year/

, 1999, Abandoned Mine Lands Initiative-Providing science for watershed issues, in Modreski, P.J., compiler, U.S. Geological Survey Open-File Report 99-321, p. 29-30.

Wilson, S.A., Briggs, P.H., Mee, J.S., and Siems, D.F., 1994, Determinations of thirty-two major and trace elements in three NIST soil SRMs using ICP-AES and WDXRF: Geostandards Newsletter, v. 18, p. 85-89. 